\title{
AKTIVITAS ANTIOKSIDAN EKSTRAK ETANOL DAUN KEJIBELING (Strobilanthes crispa L., Blume) DAN DAUN SAMBILOTO (Andrographis paniculata Burm. f. Nees) DAN KOMBINASINYA
}

\author{
Norviria Tsalasatin Apriliani dan Tukiran* \\ Jurusan Kimia, FMIPA, Universitas Negeri Surabaya, Jl. Ketintang Surabaya 60231 \\ *e-mail: tukiran@unesa.ac.id
}

Received 30 April 2021

Accepted 24 June 2021

\begin{abstract}
Abstrak
Kejibeling (Strobilanthes crispa L., Blume) dan Sambiloto (Andrographis paniculata Burm. f. Nees) adalah tanaman yang mempunyai kandungan senyawa bioaktif yang memiliki potensi sebagai antioksidan. Penelitian ini memiliki tujuan untuk mengetahui aktivitas antioksidan kombinasi ekstrak etanol daun kejibeling dan daun sambiloto. Pengujian antioksidan sampel menggunakan metode DPPH secara spektrofotometer UV-Vis. Serbuk daun kejibeling dan sambiloto dimaserasi dengan menggunakan pelarut etanol 96\% sampai diperoleh ekstrak kental setelah penguapan. Hasil uji aktivitas antioksidan didapatkan nilai IC 50 untuk ekstrak etanol kejibeling, ekstrak etanol sambiloto, kombinasi ekstrak kejibeling:sambiloto (1:1), kombinasi (1:2) dan kombinasi (2:1) berturut-turut sebesar 71,39, $15,55,7,58,7,83$ dan 6,35 ppm. Nilai IC $_{50}$ kombinasi ekstrak dari daun kejibeling dan sambiloto menunjukkan adanya peningkatan kemampuan antioksidan dibandingkan dengan ekstrak tunggal kejibeling dan sambiloto.
\end{abstract}

Kata kunci: Antioksidan, daun kejibeling, daun sambiloto, DPPH.

\begin{abstract}
Kejibeling (Strobilanthes crispa L., Blume) and Sambiloto (Andrographis paniculate Burm.f. Ness) are plants that contains bioactive compounds that have potential as antio xidant. This study aims to determine the antioxidant activity of the combination ethanol leaves extract of kejibeling and sambiloto. Antioxidant testing of samples used the DPPH method by UV-Vis spectrophotometry. Powder of kejibeling and sambiloto leaves were macerated using $96 \%$ ethanol and then evaporated until a thick extract was obtained. The results of the antioxidant activity test showed that the value of $\mathrm{IC}_{50}$ for the ethanol extract of kejibeling, ethanol extract of sambiloto, combination of kejibeling extract:sambiloto (1:1), combination (1:2) and combination (2:1) were 71.39, 15.55, 7.58, 7.83 and $6.35 \mathrm{ppm}$ respectively. The $\mathrm{IC}_{50}$ value of the combination of extracts from kejibeling and sambiloto leaves showed an increase in antioxidant ability compared to a single extract kejibeling dan sambiloto.
\end{abstract}

Keywords: Antioxidant, kejibeling leaf, sambiloto leaf, DPPH.

\section{Pendahuluan}

Gaya hidup yang tidak sehat dan dampak dari lingkungan yang buruk dapat menyebabkan sistem kekebalan dalam tubuh tidak mampu menghadapi radikal bebas. Radikal bebas bisa berasal dari dua sumber, yaitu sisa metabolisme tubuh dan beberapa faktor dari luar tubuh seperti faktor makanan, polusi udara, asap rokok serta sinar ultraviolet (Ratnayani, 2012). Kandungan radikal bebas dan antioksidan 
dalam tubuh yang tidak seimbang dapat menyebabkan stress oksidatif yang bisa merusak tubuh sehingga memicu beberapa penyakit degenerative (Bherawi, 2017).

Radikal bebas dapat diartikan sebagai atom atau molekul yang sangat reaktif karena mempunyai elektron yang tidak berpasangan pada kulit terluarnya sehingga membuatnya menjadi tidak stabil dan cenderung untuk mengikat elektron senyawa lain sehingga terbentuk radikal bebas baru yang lebih reaktif (Stankovic S dan Radovanović, 2012). Radikal bebas yang lebih reaktif tersebut cenderung terus mencari elektron di molekul sekitarnya dan apabila tidak dikendalikan maka akan terjadi reaksi berantai. Reaksi berantai tersebut dapat berhenti apabila terdapat molekul yang mendonorkan elektronnya kepada radikal bebas yang bisa disebut dengan antioksidan (Lamina S, 2013).

Antioksidan merupakan senyawa donor elektron yang bisa digunakan untuk mencegah pembentukan radikal dalam tubuh manusia dengan cara berikatan dengan molekul radikal bebas. Dengan keberadaan senyawa antioksidan tersebut dapat menetralisir terbentuknya radikal bebas dalam tubuh (Salamah, N., \& Widyasari, 2015).

Di dalam tubuh manusia sudah terbentuk suatu senyawa antioksidan dari beberapa macam enzim antioksidan, misalnya seperti enzim superoksida dismutase, glutasion peroksidase dan katalase (Werdhasari, 2014). Kurangnya senyawa antioksidan dapat menyebabkan tingginya kandungan radikal bebas dalam tubuh (Bherawi, 2017). Namun kurangnya senyawa Oleh sebab itulah, diperlukan antioksidan alami yang berasal dari tumbuhan yang dapat berpotensi untuk mencegah tingginya kandungan radikal bebas dalam tubuh (Stankovic S dan Radovanović, 2012).

Contoh tanaman dengan potensi antioksidan adalah tanaman sambiloto (Andrographis paniculate Burm.f. Ness) dan tanaman kejibeling (Strobilanthes crispa L., Blume). Tanaman kejibeling mengandung berbagai macam metabolit sekunder dan zat-zat kimia seperti kalium, natrium, asam silikat, kalsium, saponin, alkaloid, polifenol dan flavonoid yang berperan sebagai antioksidan serta dapat menghambat pertumbuhan dan perkembangan sel kanker (Andriani, 2011). Tanaman kejibeling telah banyak digunakan sebagai obat batu ginjal, batu empedu, diabetes, kolesterol dan tumor (Setyawan, 2016).

Sedangkan, tanaman sambiloto juga dapat digunakan untuk mengobati penyakit degeneratif misalnya tekanan darah tinggi, reumatik dan diabetes (Rachmani, 2018). Tanaman sambiloto dapat berkhasiat sebagai antioksidan, antiinflamasi dan antihiperglikemik (Akbar, 2011). Berdasarkan hasil penelitian Sari dkk (2014) menyatakan bahwa di dalam tanaman sambiloto terkandung berbagai senyawa fenolik dan flavonoid dengan jumlah kandungan flavonoid total dalam ekstrak etanol daun sambiloto sebesar $4,64 \pm 0,05 \% \mathrm{~b} / \mathrm{b}$ dan jumlah kandungan fenolik total dalam ekstrak etanol daun sambiloto sebesar $5,38 \pm 0,05 \% b / b$ (Sari, 2019).

Metode untuk pengujian antioksidan yang paling sering digunakan adalah metode DPPH. Radikal DPPH dengan radikal hidrogen dari antioksidan akan membentuk suatu molekul diamagnetik karena adanya elektron yang berpasangan dan menjadi lebih stabil (Bahriul, 2014). Molekul yang terbentuk akan menunjukkan serapan kuat pada panjang gelombang $517 \mathrm{~nm}$ (Jabbar, 2019).

Penelitian yang telah ada sebelumnya tentang aktivitas antioksidan pada ekstrak etanol daun kejibeling diperoleh nilai $\mathrm{IC}_{50}$ 102,85 ppm (Adibi, 2017) dan nilai IC $_{50}$ 6,5 ppm pada ekstrak daun sambiloto (Saranya, 2010). Adanya potensi antioksidan dari kedua daun tersebutlah yang melatarbelakangi dilakukannya 
penelitian tentang kombinasi dari kedua ekstrak daun tersebut sehingga nantinya diharapkan akan didapatkan hasil bahwa kombinasi dari kedua ekstrak tersebut dapat dikembangkan sebagai antioksidan alami.

Hingga saat ini, belum ada laporan yang mendokumentasikan interaksi negatif antara campuran ekstrak keji beling dengan ekstrak lain maupun sebaliknya. Selain itu, juga belum diketahui apakah campuran ekstrak etanol keji beling dan sambiloto mampu meningkatkan aktivitas antioksidan yang dihasilkan. Oleh karena itulah perlu dilakukan penelitian untuk mengetahui perbandingan aktivitas antioksidan dari kombinasi ekstrak dengan masing-masing ekstrak keji beling maupun sambiloto.

\section{Metode Penelitian}

\section{Bahan}

Dalam penelitian ini, bahan-bahan yang dibutuhkan adalah daun sambiloto kering, kejibeling kering, kertas saring, aluminium foil, etanol 96\%, metanol p.a., dan DPPH.

2. Alat

Dalam penelitian ini, alat yang dibutuhkan adalah blender, spatula, botol vial, labu ukur, corong, beaker glass, mikropipet, neraca analitik, pompa vakum, corong buchner, vacuum rotary evaporator, dan spektrofotometer UVVIS.

3. Prosedur

a. Tahap Pengumpulan dan Persiapan Sampel

Sampel daun sambiloto dan kejibeling yang didapatkan dibersihkan terlebih dahulu. Selanjutnya, daun basah tersebut dipotong-potong kecil dan kemudian diangin-anginkan di dalam ruangan selama \pm 3 hari. Sampel kering yang dihasilkan kemudian dihaluskan sampai didapatkan serbuk halus dan ditimbang sebanyak 100 gram serbuk yang siap untuk diekstraksi.

b. Tahap Ekstraksi Simplisia
Dalam toples tertutup, gunakan pelarut etanol 96\% untuk memaserasi bubuk sampel selama 1x24 jam. Saring hasil maserasi dengan menggunakan penyaring buchner sehingga diperoleh filtrat dan residu. Ulangi proses maserasi selama 3 kali.

Uapkan filtrat yang dihasilkan menggunakan vacuum rotary evaporator suhu $\pm 50{ }^{\circ} \mathrm{C}$, tekanan 13 mbar dan rotasi $60 \mathrm{rpm}$. Hasilnya adalah ekstrak etanol yang kental dan ditimbang untuk menghitung persen rendemen dengan menggunakan rumus berikut:

$\%$ Rendemen $=\frac{\text { Berat Ekstrak }}{\text { Berat Serbuk }} \times 100 \%$

(Mardiana, 2016).

c. Tahap Uji Aktivitas Antioksidan

Dimulai dengan melarutkan masingmasing 0,1 gram ekstrak etanol daun kejibeling dan sambiloto dalam methanol p.a pada labu ukur $100 \mathrm{ml}$ dan didapatkan larutan induk $1000 \mathrm{ppm}$. Selanjutnya, menyiapkan larutan uji yang dibuat dari larutan induk yang telah dibuat sebelumnya. Untuk ekstrak tunggal dan kombinasi 1:1 digunakan perbedaan konsentrasi 20, 40, 60 dan 80 ppm serta 30, 60, 90 dan 120 ppm untuk kombinasi 1:2 dan 2:1 (Novatama, S. M., Kusomo, 2016).

Kemudian ambil larutan uji tiap konsentrasi sebanyak $2 \mathrm{ml}$ yang diletakkan dalam vial gelap dan tambahkan $2 \mathrm{ml}$ larutan DPPH 0,004\%. Larutan dikocok dengan kuat dan dilakukan inkubasi larutan pada suhu 37 ${ }^{\circ} \mathrm{C}$ selama 30 menit yang kemudian diukur absorbansi dari larutan tersebut menggunakan spektrofotometer UV-Vis pada $517 \mathrm{~nm}$. Pada larutan kontrol juga diberi perlakuan yang sama dimana penggunaan larutan sampel diganti dengan methanol p.a. Selanjutnya ditentukan nilai \%inhibisi (\%I) absorban larutan DPPH serta nilai $\mathrm{IC}_{50}$. Nilai 
\%inhibisi dapat ditentukan dengan menggunakan persamaan berikut:

$\%$ Inhibisi $=\frac{\text { A blanko }- \text { A sampel }}{\text { A blanko }} \times 100 \%$

Nilai \%inhibisi kemudian dibuat kurva persamaan linier dan persamaan yang didapatkan tersebut digunakan untuk menghitung nilai $\mathrm{IC}_{50}$. Nilai $\mathrm{IC}_{50}$ didapatkan dengan cara mengganti y pada persamaan linier dengan nilai 50 dan $\mathrm{x}$ yang didapatkan merupakan nilai $\mathrm{IC}_{50}$ (Pangestu, 2017).

\section{Hasil dan Pembahasan}

Kejibeling dan sambiloto adalah tanaman yang sering digunakan sebagai obat tradisional. Hal tersebut disebabkan karena pada kedua jenis tanaman tersebut terkandung beberapa senyawa metabolit sekunder dan zat kimia lainnya yang dapat berpotensi sebagai sumber antioksidan alami. Daun kejibeling memiliki kandungan senyawa polifenolik, saponin, alkaloid, kumarin, flavonoid, kalium dan kalsium (Dita, 2017) dan dalam daun sambiloto terdapat kandungan senyawa andrographolide, terpenoid, tannin, saponin, alkaloid, fenolik dan flavonoid (Wardatun, 2011).

Kandungan flavonoid yang terdapat di dalam daun kejibeling dan sambiloto dapat berpotensi sebagai antioksidan (Lipinski, 2011). Flavonoid dapat berpotensi sebagai antioksidan karena flavonoid memiliki sifat sebagai suatu akseptor yang baik terhadap radikal bebas (Sudarmanto, 2015). Flavonoid akan berikatan dengan radikal bebas membentuk senyawa baru yang tidak reaktif sehingga bersifat stabil. Oleh sebab itu, flavonoid dapat menghambat proses terjadinya oksidasi (Simanjuntak, 2012). Flavonoid akan melakukan penangkapan radikal bebas dengan cara mendonorkan proton hidrogen dari gugus hidroksil yang dimilikinya (Rachmani, 2018). Selain flavonoid, di dalam daun sambiloto juga terkandung senyawa andrographolid dan neoandrographolid yang merupakan kelompok glukosida yang dapat berpotensi sebagai suatu antioksidan kuat (Mahardika, 2020).

Dalam penelitian ini, digunakan simplisia daun kejibeling dan daun sambiloto kering. Tujuannya adalah untuk memperkecil kemungkinan sampel terkontaminasi oleh jamur dan menghentikan proses enzimatik dalam sampel karena dapat menyebabkan zat aktif yang terkandung dalam sampel semakin terurai (Pangestu, 2017), agar sampel yang digunakan lebih awet dalam kondisi kering dan kadar airnya menjadi berkurang sehingga pelarut akan lebih mudah menarik senyawa-senyawa bioaktif yang terkandung di dalam sampel (Dewi, 2014). Kemudian sampel dihaluskan dengan tujuan untuk memperluas kontak yang terjadi antara sampel dengan pelarut yang digunakan (Adibi, 2017). Hal ini dikarenakan ukuran partikel yang semakin kecil akan semakin memperluas permukaan partikel sehingga proses maserasi dapat dilakukan lebih efektif (Jabbar, 2019).

Pada penelitian ini digunakan proses ekstraksi dengan teknik maserasi. Dipilih proses ekstraksi teknik maserasi karena teknik tersebut termasuk dalam jenis ekstraksi dingin. Jenis ekstraksi dingin dapat digunakan untuk mencegah kerusakan komponen kimia dalam sampel yang tidak tahan panas, seperti senyawa antioksidan (Syukur, 2011). Antioksidan merupakan salah satu senyawa yang tidak tahan terhadap panas karena antioksidan mudah mengalami degradasi jika berada pada suhu yang tinggi dengan waktu lama sehingga akan kehilangan kemampuannya dalam mendonorkan elektron untuk menetralkan senyawa radikal bebas (Mahardika, 2020).

Pada proses ekstrasi ini menggunakan pelarut etanol 96\%. Pelarut etanol dipilih karena mempunyai gugus polar sekaligus gugus nonpolar sehingga dapat melarutkan senyawa-senyawa kimia yang bersifat polar, nonpolar maupun semi polar (Adibi, 2017), seperti flavonoid, 
steroid, alkaloid dan asam lemak yang memiliki potensi sebagai antioksidan (Herman, 2013). Selain itu pelarut etanol merupakan suatu pelarut yang memiliki sifat polar sehingga dapat melarutkan senyawa antioksidan pada sampel yang umumnya bersifat polar (Wardatun, 2011).

Setelah sampel tersebut dimaserasi, hasil maserasi yang berupa ekstrak cair diuapkan menggunakan vacuum rotary evaporator untuk memisahkan pelarut etanol dari ekstrak yang dihasilkan. Alat vacuum rotary evaporator memiliki kemampuan untuk menguapkan pelarut di bawah titik didihnya. Hal tersebut dapat terjadi karena pada alat vacuum rotary evaporator juga terdapat pompa vakum yang dapat mengurangi tekanan pada permukaan sehingga membuat pelarut yang digunakan mengalami penguapan di bawah titik didihnya sehingga dapat mencegah kerusakan komponen bioaktif yang terkandung di dalam sampel akibat adanya pemanasan pada suhu yang terlalu tinggi.

Hasil ekstraksi yang diperoleh, yaitu berupa ekstrak kental. Pembuatan ekstrak kental tersebut agar pelarut yang digunakan hilang sehingga diharapkan dihasilkan ekstrak yang hanya berisi komponen bioaktif dari serbuk simplisia tanpa ada pengaruh dari pelarut yang telah digunakan untuk ekstraksi (Setyawan, 2016). Dihasilkan ekstrak kental kejibeling sebanyak 10,314 gram dan sambiloto 11,791 gram dengan persen rendemen 10,314\% untuk kejibeling dan $11,791 \%$ untuk sambiloto. Nilai rendemen yang tinggi menunjukkan bahwa semakin banyak kandungan senyawa bioaktif dalam sampel (Kiswandono, 2011).

Aktivitas antioksidan diukur dengan menggunakan metode DPPH secara spektrofotometer UV-Vis. Peredaman DPPH dapat ditandai dari intensitas warna yang dihasilkan. Besarnya peredaman DPPH sebanding dengan konsentrasi. Jika konsentrasi ekstrak lebih tinggi, maka reduksi DPPH akan semakin besar sehingga warna larutan menjadi lebih kuning. Adanya perubahan intensitas warna larutan disebabkan karena reaksi antara atom hidrogen yang berasal dari senyawa antioksidan dalam sampel dengan DPPH sehingga membentuk suatu senyawa baru difenil pikril hidrazin (DPPH2) yang disertai dengan terjadinya peluruhan warna DPPH menjadi warna kuning. Oleh sebab itu, dibuat konsentrasi ekstrak yang berbeda-beda untuk mengetahui tingkat peredaman warna ungu DPPH oleh antioksidan. Penurunan intensitas dari warna tersebut berbanding lurus dengan jumlah senyawa radikal bebas DPPH yang dapat diredam oleh senyawa antioksidan sehingga membuat absorbansinya menjadi semakin rendah. Oleh sebab itulah semakin kecilnya nilai absorbansi dari larutan berarti menunjukkan semakin banyak senyawa antioksidan dalam sampel (Rachmani, 2018).

Perubahan warna pada DPPH itulah yang nantinya akan dijadikan acuan pengukuran intensitas warna larutan menggunakan spektrofotometer UV-Vis $517 \mathrm{~nm}$. Penelitian ini menggunakan 4 variasi konsentrasi larutan, yaitu 20, 40, 60 dan 80 ppm untuk ekstrak tunggal dan kombinasi 1:1 serta 30, 60, 90 dan 120 ppm untuk kombinasi 1:2 dan 2:1. Tabel 1 menyajikan tentang hasil uji aktivitas antioksidan daun kejibeling dan sambiloto beserta kombinasinya.

Pada tabel 1 terlihat bahwa dengan bertambahnya konsentrasi larutan, nilai absorbansi semakin kecil dan nilai persen inhibisi semakin besar. Penurunan nilai absorbansi tersebut disebabkan karena adanya radikal bebas DPPH yang tereduksi oleh senyawa antioksidan. Jika konsentrasi sampel semakin tinggi, maka absorbansi larutan menjadi semakin menurun. Hal tersebut disebabkan karena semakin banyaknya senyawa antioksidan dalam sampel sehingga peredaman DPPH juga semakin banyak (Talapessy, 2013). 
Berkebalikan dengan absorbansi, semakin tinggi konsentrasi sampel maka persen inhibisi akan semakin meningkat yang disebabkan karena persen inhibisi menyatakan kemampuan ekstrak sebagai penghambat terbentuknya radikal bebas. Ketika konsentrasi dari ekstrak meningkat maka kemampuan menghambat dari antioksidan dalam sampel juga akan semakin besar (Damanis, 2020).

Tabel 1. Hasil Uji Aktivitas Antioksidan Sampel

\begin{tabular}{|c|c|c|c|c|}
\hline Sampel & $\begin{array}{l}\mathrm{C} \\
(\mathrm{ppm})\end{array}$ & $\begin{array}{l}\text { Abs. } \\
\text { blanko }\end{array}$ & $\begin{array}{l}\text { Abs. } \\
\text { sampel }\end{array}$ & $\% \mathrm{I}$ \\
\hline $\begin{array}{l}\text { Daun } \\
\text { Kejibeling }\end{array}$ & $\begin{array}{l}20 \\
40 \\
60 \\
80\end{array}$ & 0,5665 & $\begin{array}{c}0,5386 \\
0,5341 \\
0,53 \\
0,5279\end{array}$ & $\begin{array}{l}4,92 \\
5,71 \\
6,44 \\
6,81\end{array}$ \\
\hline $\begin{array}{l}\text { Daun } \\
\text { Sambiloto }\end{array}$ & $\begin{array}{l}20 \\
40 \\
60 \\
80\end{array}$ & 0,5665 & $\begin{array}{l}0,3841 \\
0,3743 \\
0,3686 \\
0,3632\end{array}$ & $\begin{array}{l}32,19 \\
33,92 \\
34,93 \\
35,88\end{array}$ \\
\hline $\begin{array}{l}\text { Kombinasi } \\
\mathrm{Kj}: \mathrm{Sb} \\
(1: 1)\end{array}$ & $\begin{array}{l}20 \\
40 \\
60 \\
80\end{array}$ & 0,5665 & $\begin{array}{c}0,3972 \\
0,3854 \\
0,3675 \\
0,344\end{array}$ & $\begin{array}{l}29,88 \\
31,96 \\
35,12 \\
39,27\end{array}$ \\
\hline $\begin{array}{l}\text { Kombinasi } \\
\mathrm{Kj}: \mathrm{Sb} \\
(1: 2)\end{array}$ & $\begin{array}{c}30 \\
60 \\
90 \\
120\end{array}$ & 0,5665 & $\begin{array}{c}0,477 \\
0,4475 \\
0,4163 \\
0,3935\end{array}$ & $\begin{array}{l}15,79 \\
21,00 \\
26,51 \\
30,53\end{array}$ \\
\hline $\begin{array}{l}\text { Kombinasi } \\
\mathrm{Kj}: \mathrm{Sb} \\
(2: 1)\end{array}$ & $\begin{array}{c}30 \\
60 \\
90 \\
120\end{array}$ & 0,5665 & $\begin{array}{c}0,3271 \\
0,319 \\
0,3111 \\
0,3024\end{array}$ & $\begin{array}{l}42,25 \\
43,68 \\
45,08 \\
46,61\end{array}$ \\
\hline
\end{tabular}

Untuk mengetahui nilai $\mathrm{IC}_{50}$ dari ekstrak, dibuat kurva persamaan linear terlebih dahulu dengan memplotkan konsentrasi dan persen inhibisi. Hasil dari pembuatan kurva persamaan linear dari ekstrak tunggal dan kombinasinya ditunjukkan dalam gambar 1-5 berikut.

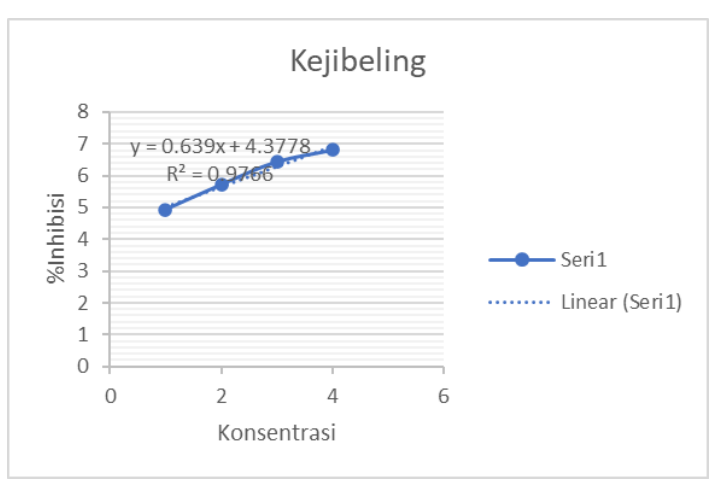

Gambar 1. Kurva Antioksidan Ekstrak Etanol Daun Kejibeling

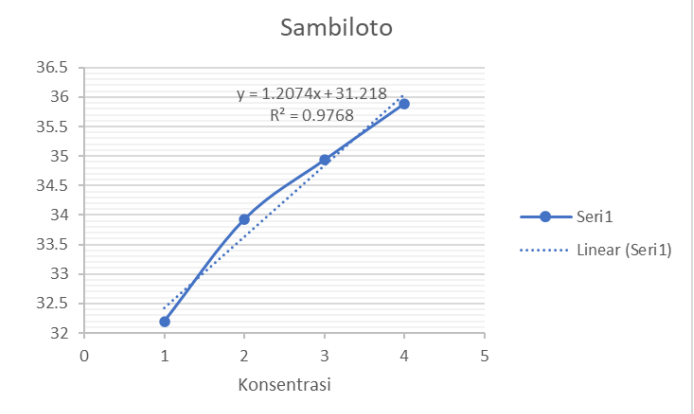

Gambar 2. Kurva Antioksidan Ekstrak Etanol Daun Sambiloto

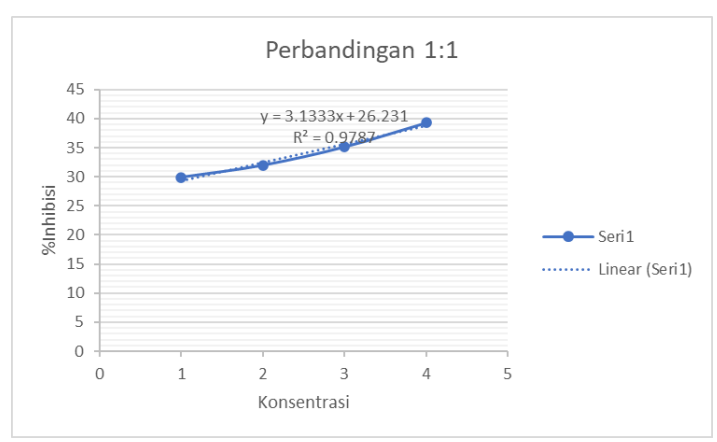

Gambar 3. Kurva Antioksidan Kombinasi Ekstrak kejibeling : Sambiloto (1:1) 


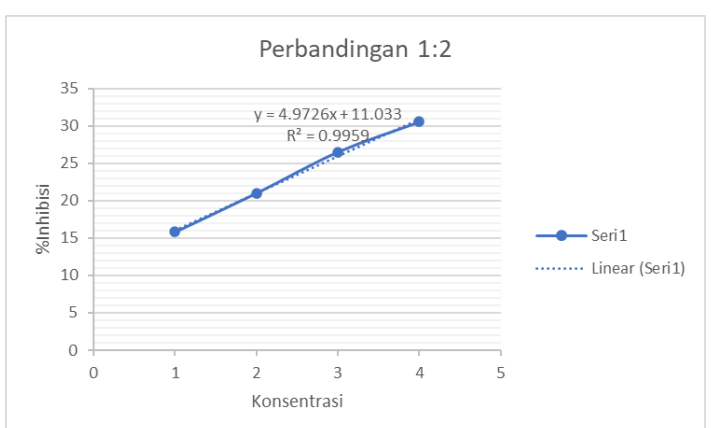

Gambar 4. Kurva Antioksidan Kombinasi Ekstrak Kejibeling : Sambiloto $(1: 2)$

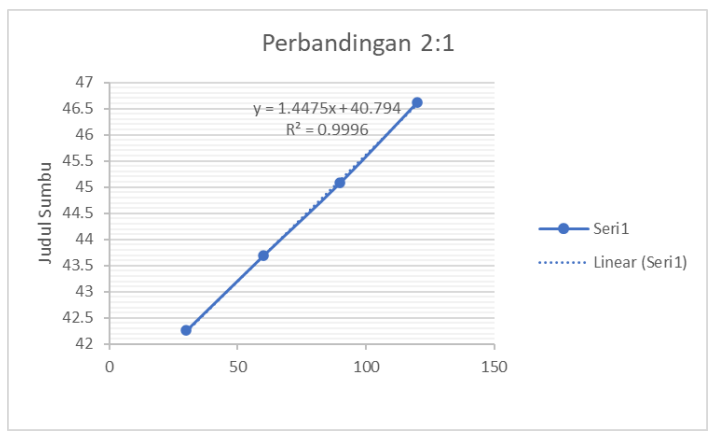

Gambar 5. Kurva Antioksidan Kombinasi Ekstrak Kejibeling : Sambiloto $\mathrm{C}$

Berdasarkan hasil analisis nilai regresi linier maka didapatkan persamaan regresi yang digunakan dalam menghitung nilai $\mathrm{IC}_{50}$ dari ekstrak sampel dan diperoleh nilai $\mathrm{IC}_{50}$ yang disajikan pada tabel 2 dibawah ini.

Tabel 2. Nilai $\mathrm{IC}_{50}$ Ekstrak Etanol Kejibeling dan Sambiloto beserta Kombinasinya

\begin{tabular}{lc}
\cline { 2 - 2 } \multicolumn{1}{c}{ Sampel } & IC50 \\
Ekstrak Etanol Kejibeling & 71,39 \\
Ekstrak Etanol Sambiloto & 15,55 \\
Ekstrak Etanol Kombinasi 1:1 & 7,58 \\
Ekstrak Etanol Kombinasi 1:2 & 7,83 \\
Ekstrak Etanol Kombinasi 2:1 & 6,35 \\
\hline
\end{tabular}

Nilai IC $_{50}$ memiliki arti bahwa pada konsentrasi tersebut ekstrak yang digunakan dapat meredam 50\% dari DPPH. Berdasarkan tabel 2, didapatkan nilai $\mathrm{IC}_{50}$ dari ekstrak etanol daun kejibeling dan sambiloto yang lebih kecil dari hasil penelitian yang dilakukan Adibi, dkk. (2017) diperoleh nilai $\mathrm{IC}_{50}$ daun kejibeling 102,85 ppm dan dari Saranya et al. (2010) diperoleh nilai $\mathrm{IC}_{50}$ daun sambiloto 6,5 ppm. Adanya perbedaan nilai $\mathrm{IC}_{50}$ yang dihasilkan tersebut dapat disebabkan karena adanya faktor geografis, faktor genetik, kondisi iklim, asal benih dan tingkat kesuburan tanah yang mempengaruhi kandungan senyawa dalam tanaman (Giridhari, 2011).

Berdasarkan nilai $\mathrm{IC}_{50}$ yang dihasilkan tersebut dapat diketahui bahwa daun kejibeling dan daun sambiloto dapat berpotensi sebagai antioksidan alami. Hal tersebut disebabkan karena di dalam daun kejibeling dan sambiloto terdapat senyawa antioksidan seperti flavonoid dan fenolik. Senyawa flavonoid dan fenolik dapat digunakan sebagai antioksidan karena mampu menyumbangkan proton hidrogen dari gugus hidroksilnya sehingga senyawa DPPH akan tereduksi menjadi senyawa non-radikal yang stabil (DPPH2).

Apabila diperoleh nilai $\mathrm{IC}_{50}<50 \mathrm{ppm}$ maka tergolong antioksidan sangat kuat, $\mathrm{IC}_{50}$ 50-100 ppm kuat, IC $\mathrm{IC}_{50} 100-150$ ppm sedang, $\mathrm{IC}_{50} 151-200 \mathrm{ppm}$ lemah dan $\mathrm{IC}_{50}$ $>200$ ppm merupakan antioksidan sangat lemah (Rachmani, 2018). Berdasar literatur, dapat disimpulkan bahwa pada penelitian ini ekstrak etanol daun kejibeling tergolong antioksidan kuat, sedangkan ekstrak etanol sambiloto, kombinasi ekstrak 1:1, kombinasi ekstrak 1:2 dan kombinasi ekstrak 2:1 tergolong ke dalam antioksidan sangat kuat. Dengan demikian, ekstrak kombinasi dari kedua jenis tumbuhan tersebut dapat dikembangkan lebih lanjut sebagai senyawa antioksidan alami khususnya pada kombinasi ekstrak kejibeling: sambiloto 2:1 karena pada perbandingan kombinasi tersebut memiliki aktivitas antioksidan yang paling tinggi dibandingkan dengan variasi perbandingan kombinasi yang lain. Namun, penelitian tentang uji aktivitas antioksidan pada kombinasi kedua jenis tanaman dengan menggunakan metode 
yang berbeda perlu dilakukan untuk mengkaji lebih luas terkait dengan mekanisme dari kombinasi kedua ekstrak sebagai suatu agen antioksidan.

\section{Kesimpulan}

Berdasarkan data yang dihasilkan dapat disimpulkan bahwa dari nilai $\mathrm{IC}_{50}$ yang diperoleh pada penelitian ini menunjukkan adanya peningkatan aktivitas antioksidan dari ekstrak kombinasi daun kejibeling dan sambiloto dibandingkan ekstrak tunggalnya dengan nilai terbaik terdapat pada perbandingan kombinasi 2:1. Hasil uji aktivitas antioksidan menghasilkan nilai $\mathrm{IC}_{50}$ untuk ekstrak etanol kejibeling, ekstrak etanol sambiloto, kombinasi ekstrak kejibeling:sambiloto (1:1), kombinasi (1:2) dan kombinasi (2:1) berturut-turut sebesar 71,39, 15,55, 7,58, 7,83 dan 6,35 ppm. Pada kedua jenis ekstrak tanaman ini, yang paling berperan sebagai antioksidan adalah senyawa flavonoid dan fenolik.

\section{DAFTAR PUSTAKA}

Adibi, S. d. (2017). Aktivitas Antioksidan dan Antibakteri Ekstrak Daun Strobilanthes crispus Bl (Keji Beling) Terhadap Staphylococcus aureus dan Escherichia coli. Alotrop, 1(2), 148154.

Akbar, S. (2011). Andrographis paniculata: A Review of Pharmacological Activities and Clinical Effects. Journal of AMR, 16(1), 66-77.

Andriani, Y. M. (2011). Antibacterial, radical scavening activities and cytotoxicity properties of Phaleria macrocarpa (scheff.) Boerl. Leaves in Hepg2 cell lines. International Journal of Pharmaceutical Sciences and Research, 2(1), 1700-1706.

Bahriul, D. (2014). Uji Aktivitas Antioksidan Ekstrak Daun Salam (Szygium polyanthum) Dengan Menggunakan 1,1-difenil- 2picrilhidrazyl. Jurnal Akademika Kimia, 3(3), 143-149.

Bherawi, K. N. dan T. A. (2017). Efek Aktivitas Fisik pada Proses Pembentukan Radikal Bebas sebagai Faktor Risiko Aterosklerosis. Majority, 6(2), 85-90.

Damanis, D. (2020). Uji Aktivitas Antioksidan Ekstrak Etanol Ascidian (Herdmania Momus) dengan Metode DPPH (1,1-difenil-2-pikrilhidrazil). Pharmacon, 9(3), 464-469.

Dewi, D. (2014). Aktivitas Antioksidan Senyawa Flavonoid Ekstrak Etanol Biji Terong Belanda (Solanum Betaceum, Syn) dalam Menghambat Reaksi Peroksidasi Lemak Pada Plasma Darah Tikus Wistar. Cakra Kimia, 2(1), 7-16.

Dita, A. \& S. F. (2017). Efektivitas Perasan Daun Keji Beling (Sericocalyx crispus Linn) dalam Menghambat Pertumbuhan Staphylococcus aureus. The Journal of Muhammadiyah Medical Laboratory Technologist, 2(1), 78-83.

Giridhari, V. V. (2011). Anti-diabetic properties of drumstick (Moringa oleifera) leaf tablets. Int J Health Nutr, 2(1), 1-5.

Herman. (2013). Aktivitas Antioksidan Beberapa Tumbuhan Obat Kalimantan Timur. Journal of Tropial Pharmacy and Chemistry, 2(2), 100-104. https://doi.org/doi:10.25026/jtpc.v2i2. 54

Jabbar, D. (2019). Aktivitas Antioksidan Ekstrak Etanol Buah, Daun, Batang Dan Rimpang Pada Tanaman Wualae (Etlingera Elatior (Jack) R.M Smith). Jurnal Farmasi Galenika (Galenika Journal of Pharmacy), 5(2), 189-197.

Kiswandono, D. (2011). Uji antioksidan ekstrak heksana, etil asetat, etanol, metanol $80 \%$ dan air daun kelor (Moringa oleifera Lamk). Jurnal Sains Natural Universitas Nusa Bangsa, 1(1), 39-44.

Lamina S, dkk. (2013). Effects of free radicals and antioxidants on exercise 
performance. Oxidants and Antioxidants in Medical Science, 2(2), 83-91.

Lipinski, B. (2011). Hydroxyl Radical and Its Scavengers in Health and Disease. Review Article. Oxidative Medicine and Cellular Longevity, 11, 1-9.

Mahardika, dkk. (2020). Ekstrak Etanol Daun Sambiloto (Andrographis Paniculata) Menurunkan HAI (Histology Activity Indeks)-Knodell Score Pada Hepar Mencit (Mus Musculus) Jantan Yang Diinduksi CCl4. Jurnal Medika Udayana, 9(4), 75-80.

Mardiana, R. N. \& N. H. (2016). Uji Aktivitas Antibakteri Ekstrak Daun Sambiloto (Andrographis paniculata) terhadap Bacillus cereus dan Pseudomonas aeruginosa. Biofarmasi, 14(1), 19-24.

Novatama, S. M., Kusomo, E. \& S. (2016). Identifikasi betasianin dan uji antioksidan ekstrak buah bit merah (Beta vulgaris L.). Indo. J. Chem. Sci, 5(3), 217-220.

Pangestu, dkk. (2017). Aktivitas Antioksidan dan Antibakteri Ekstrak Daun Jatropha gossypifolia L. Alotrop, 1(1), 15-19.

Rachmani, E. P. N. (2018). Aktivitas Antioksidan Fraksi Flavonoid Bebas Andrografolid dari Herba Sambiloto (Andrographis paniculata). Pharmacy Medical Journal, 2(1), 42-49.

Ratnayani, K. A. (2012). Kadar total senyawa fenolat pada madu randu dan madu kelengkeng serta uji aktivitas antiradikal bebas dengan Metode DPPH (difenilpikril hidrazil). J. Kim, 6, 163-168.

Salamah, N., \& Widyasari, E. (2015). Aktivitas antioksidan ekstrak metanol daun kelengkeng (Euphoria longan L.) dengan metode penangkapan radikal 2,2'-difenil-1-pikrilhidrazil.

Pharmaciana, 5(1), 25-34.

Saranya, e. a. (2010). The antioxidant and $\mathrm{h}+\mathrm{k}+$ atpase inhibitory effect of andrographis paniculata and andrographolide in vitro and in vivo studies. Pharmacologyonline, 1, 356376.

Sari, dkk. (2019). Efek Ekstrak Kombinasi Herba Andrographis paniculata (Burm.f) Ness dan Daun Gynura Procumbens (Merr) dalam Penangkapan Senyawa Radikal Bebas. Majalah Farmaseutik, 15(1), 16-21.

Setyawan, A. W. (2016). Pembuktian Ekstrak Daun Kejibeling Dalam Meningkatkan Sistem Imun. Jurnal Kesehatan Masyarakat, KEMAS, 11(2), 96-100.

Simanjuntak, K. (2012). Peran Antioksidan Flavonoid dalam Meningkatkan Kesehatan. Bina Widya, 23(3), 135-140.

Stankovic S dan Radovanović. (2012). Oxidative stress and physical activity. Sportlogia, 8(1), 1-11.

Sudarmanto, I. \& T. S. (2015). Aktivitas Antioksidan Senyawa Flavonoid Pada Kulit Akar Tanaman Ara (Ficus racemosa, L). Jurnal Kesehatan, 6(2), 137-141.

Syukur, R. A. (2011). Aktivitas Antiradikal Bebas Beberapa Ekstrak Tanaman Familia Fabaceae. JST Kesehatan, 1(1), 61-67.

Talapessy, S. S. (2013). Uji Aktivitas Antioksidan dari Ampas Hasil Pengolahan Sagu (Metroxylon sagu rottb). Jurnal Ilmiah Farmasi, 2(3), 40-44.

Wardatun, S. (2011). Uji Aktivitas Antioksidan Ekstrak Etanol Akar, Kulit Batang dan Daun Tanaman Sambiloto (Andrographis paniculata Ness.) Dengan Metode Linoleat-Tiosianat. Fitofarmaka, 1(2), 9-13.

Werdhasari, A. (2014). Peran antioksidan bagi kesehatan. J. Biotek Medisiana Indonesia, 3(2), 59-68. 